\title{
Formulasi Bubuk Bunga Cengkeh (Syzygium Aromaticum) Dalam Media Teri Ubi Rumput Laut Medium (TURLM) Formula 3 Sebagai Zat Penghambat Jamur Kontaminan Pada Biakan Mycobacterium Tuberculosis
}

Rohmi $^{1}$, Faharuddin Ahad ${ }^{1}$, Maruni Wiwin Diarti ${ }^{1}$

${ }^{1}$ Prodi D.IV Analis Kesehatan, Poltekkes Kemenkes Mataram

\begin{tabular}{l} 
Article Info \\
\hline Article history: \\
Received Jan $13^{\text {th }}, 2020$ \\
Revised Feb $12^{\text {th }}, 2020$ \\
Accepted Feb $16^{\text {th }}, 2020$ \\
\hline
\end{tabular}

Keyword:

Clove Flower (Syzygium aromaticum,

Medium Seaweed Cassava

Media (TURLM),

Contaminant Fungus,

Mycobacterium tuberculosis

\begin{abstract}
The diagnosis of tuberculosis has so far been made based on direct microscopic examination of sputum by staining Acid Resistant Bacteria (BTA). Inspection by the culture method has several disadvantages, namely the incubation period that is too long to count growth. an effort is needed to explore natural ingredients that can be added to the TURLM media formulation so that it can inhibit the growth of fungal contamination without affecting the growth of Mycobacterium tuberculosis. The purpose of this study was to determine the clove flower formulation (Syzygium aromaticum) in Medium Seaweed Cassava Media (TURLM) Formula 3 as a Contaminant Inhibiting Fungi in Mycobacterium tuberculosis Culture. Design experimental research in a laboratory using the design of The Posttest Only Control Group. Data from observations of colony growth in each of the combination formulas of the TURLM Formula 3 (three) Clove Powder flower and Loweinstein-Jensen's comparison media were analyzed descriptively. The results showed that the texture of the media between the three TURLM 3 formulas with the addition of clove powder did not show a significant difference either in texture hardness, homogeneity, odor and surface. Media TURLM formula 3 without clove powder and Loweinstein - Jenssen showed growth of fungal colonies of Aspergillus flavus, Aspergillus niger and contaminant bacteria Staphylococcus albus, growth rate on day 5 and growth fertility rate of 4 (four), while on the media of clove flower formulation asphalt (Syzygium aromaticum) in medium 3 Seaweed Sweet Potato (TURLM) medium in formulations 1,2 and 3 to the 8th week of observation showed the results of the growth of contaminant fungi and M. tuberculosis were negative. The conclusion of this study is that the formula 3 TURLM media added clove powder to all formulas can prove to be very effective in inhibiting the growth of contaminant fungi and inhibiting $M$. tuberculosis, so that it can be developed for antifungal in all media products that are susceptible to fungal contamination, especially in media growth of M. tuberculosis.
\end{abstract}

Copyright (C) Jurnal Keperawatan Prima All rights reserved.

\footnotetext{
ABSTRAK

Diagnosis tuberculosis sampai saat ini masih ditegakkan berdasarkan pemeriksaan sputum secara mikroskopis langsung dengan pewarnaan Bakteri Tahan Asam (BTA). Pemeriksaan dengan metode kultur memiliki beberapa kelemahan yaitu masa inkubasi yang terlalu panjang untuk menghitung pertumbuhan. maka diperlukan suatu usaha untuk mengeksplorasi bahan alam yang bisa ditambahkan dalam formulasi media TURLM sehingga bisa menghambat pertumbuhan jamur kontaminasi tanpa mempengaruhi pertumbuhan Mycobacterium tuberculosis. Tujuan penelitian ini adalah mengetahui Formulasi Bubuk bunga Cengkeh
} 
(Syzygium aromaticum) dalam Media Teri Ubi Rumput Laut Medium (TURLM) Formula 3 Sebagai Zat Penghambat Jamur Kontaminan pada Biakan Mycobacterium tuberculosis. Desain penelitian eksperiment di laboratorium dengan menggunakan desain The Posttest Only Control Group. Data dari hasil pengamatan pertumbuhan koloni pada masing - masing media formula kombinasi Bubuk bunga Cengkeh TURLM Formula 3 (tiga) dan media pembandingan Loweinstein - Jensen dilakukan analisis secara deskriptif. Hasil penelitian menunjukkan bahwa gambaran tekstur media antara ketiga formula TURLM 3 dengan penambahan bubuk cengkeh tidak menunjukkan perbedaan yang signifikan baik dalam tekstur kekerasan, homogenitas, bau dan permukaan. Media TURLM formula 3 tanpa bubuk cengkeh dan Loweinstein - Jenssen menunjukkan pertumbuhan koloni jamur kontaminan Aspergillus flavus, Aspergillus niger dan bakteri kontaminan Staphylococcus albus, kecepatan pertumbuhan pada hari ke -5 dan angka kesuburan pertumbuhan 4 (empat), sedangkan pada media formulasi bubuk bunga Cengkeh (Syzygium aromaticum ) dalam media Teri Ubi Rumput Laut Medium (TURLM) formula 3 baik pada formulasi 1,2 dan 3 sampai dengan minggu ke -8 pengamatan menunjukkan hasil pertumbuhan koloni jamur kontaminan dan M. tuberculosis negative. Kesimpulan dari penelitian ini adalah media TURLM formula 3 yang ditambahkan bubuk cengkeh pada semua formula mampu membuktikan sangat efektif dalam menghambatan pertumbuhan jamur kontaminan dan menghambat $M$. tuberculosis, sehingga dapat dikembangkan untuk anti jamur pada semua produk media yang rentan terhadap kontaminasi jamur, terutama pada media pertumbuhan $M$. tuberculosis.

Kata Kunci : Bunga Cengkeh (Syzygium aromaticum), Media Teri Ubi Rumput Laut Medium (TURLM), Jamur Kontaminan, Mycobacterium tuberculosis

Copyright $\odot$ JAMBS

\section{Pendahuluan}

Media merupakan suatu bahan yang terdiri atas campuran nutrisi yang dipakai untuk menumbuhkan mikroba. Untuk membuat media suatu mikroba, titik tolaknya harus dimulai dari medium dasar mineral yaitu suatu medium yang mengandung unsur-unsur yang dapat diberikan dalam bentuk senyawa anorganik. Medium dasar ini selanjutnya dapat ditambah dengan senyawa-senyawa lain jika diperlukan, misalnya sumber karbon, sumber energi, sumber nitrogen, faktor pertumbuhan, dan faktor lingkungan yang lain. Meskipun persyaratan nutrien mikroba amat beranekaragam, namun sebagai makluk hidup mereka mempunyai kebutuhan dasar yang sama, yaitu meliputi air, karbon, energi, mineral dan faktor pertumbuhan (Murray, 2005).

Media pertumbuhan yang umum digunakan dan merupakan gold standart untuk menumbuhkan Mycobacterium tuberculosis adalah Lowenstein-Jensen dan Ogawa yang mengandung malasit green untuk menghambat bakteri lain kemudian memodifikasi dengan citrat dan phosphat. Komposisi dari asam lemak dan protein esensial untuk metabolisme bakteri. Glyserol bersumber dari carbon dan energi yang dibutuhkan untuk tipe human tubercle bacillus daripada bovine tipe. Asparagin dan RNA ditumbuhkan untuk menyediakan sumber nitrogen dan stimulant pertumbuhan koagulasi dari albumin telur perlu diperhatikan selama proses mencampurkan telur dengan media jangan dalam keadaan panas karena dapat mengakibatkan kematangan pada telur. Inspirasi menyediakan medium solid untuk inokulasi kultur spesimen dari mikroba selalu berisi campuran kontaminasi mikroorganisme sehingga mengharuskan menggunakan antibiotik selektif di dalam media untuk isolasi. Asam nalidixic menghambat bakteri Gram (-). Lincomycin menghambat Gram (+). Cycloheximide menekan jamur saprofit (Crofton SJ; Horne N; Miller F, 2002).

Diagnose tuberculosis sampai saat ini masih ditegakkan berdasarkan pemeriksaan sputum secara mikroskopis langsung dengan pewarnaan Bakteri Tahan Asam (BTA), dilanjutkan dengan pemeriksaan kultur untuk konfirmasi identifikasi yang keperluan uji sensitivity antibiotika. Umumnya kultur biakan menggunakan media Loewenstein Jensen (LJ) dan Ogawa medium dengan ciri morfologi koloni M. tuberculosis adalah sebagai berikut: kasar, kering, rapuh, tengah bertumpuk dengan tepi berjejas tipis; kadang-kadang tipis dan menyebar. Hari tumbuh $12-28$ hari dan tidak berpigmen baik pada tempat yang terang maupun gelap (buff) (Crofton SJ; Horne N; Miller F, 2002; Srigede L dkk., 2013).

Pemeriksaan dengan metode kultur memiliki beberapa kelemahan yaitu masa inkubasi yang terlalu panjang untuk menghitung pertumbuhan $M$. tuberculosis yang mencapai 8 minggu untuk bisa menyatakan hasil negatif. Komposisi media LJ yang relatif menggunakan bahan - bahan seperti Potato flour 30.0 gram, Asparagine 3,6 gram, Monopotassium phosphate 2,4 gram, Magnesium citrate 0,6 gram, Malacit green 0,4 gram, Magnesium sulfat 0,24 gram, Whole Eggs 1000,0 ml, Gliserol 12,0 ml dan Demineralized water $600 \mathrm{ml}$, membuat media ini harganya relatif mahal dan memerlukan pembuatan yang khusus yang memerlukan ketelitian (Murray,P.R dkk., 2007). Permasalahan dari kelemahan media kultur ini mendasari pencarian bahan - bahan alam sebagai bahan alternatif yang dapat digunakan untuk pertumbuhan $M$. tuberculosis, dengan membuat analisis formula untuk eksplorasi formula pertumbuhan $M$. tuberculosis yang bersifat eksperimen di laboratorium menggunakan bahan alam dan pangan lokal. 
Hasil penelitian Rohmi dan Diarti (2018) menunjukkan bahwa pola sensitivitas dan spesifisitas media Teri Ubi Rumput Laut Medium (TURLM) formula 3 terhadap pertumbuhan $M$. tuberculosis dibandingkan dengan media baku standart Loweinstein - Jensen berdasarkan positifitas pertumbuhan adalah sensitivitas $100 \%$ dan spesifisitas 100\%. Pola waktu kecepatan pertumbuhan M. tuberculosis pada media Teri Ubi Rumput Laut Medium (TURLM) formula 3 lebih cepat dibandingkan dengan media baku standart Loweinstein Jensen. Pola jumlah koloni pertumbuhan M. tuberculosis pada media Teri Ubi Rumput Laut Medium (TURLM) formula 3 lebih banyak dari pada media baku standart Loweinstein-Jensen. Pola Angka kesuburan pertumbuhan M. tuberculosis pada media Teri Ubi Rumput Laut Medium (TURLM) formula 3 sama dengan media baku standart Loweinstein - Jensen.

Tanaman cengkeh (Syzigium aromaticum) merupakan tanaman rempah yang dapat ditemukan di Indonesia dan dimanfaatkan dalam industri rokok, makanan dan obat-obatan (Sidabutar, 2016). Berdasarkan hasil penelitian di Balittro (Balai Penelitian Tanaman Rempah dan Obat), produk cengkeh berupa daun, gagang bunga, minyak cengkeh dan eugenol dapat menekan bahkanme matikan pertumbuhan miselium jamur, koloni bakteri dan nematoda. Karena itu produk cengkeh dapat digunakan sebagai fungisida, bakterisida, nematisida dan insektisida. Sebagai fungisida cukup potensial terutama untuk jenis pathogen tanah antara lain $P$. capsici, $R$. lignosus, Sclerotiumsp dan F. oxysporum (Nurdjannah, 2016).

Minyak cengkeh memiliki aktivitas biologi aktivitas biologi, antara lain sifat antibakteri, antijamur, pemberantas serangga, dan antioksidan, dan secara tradisional digunakan sebagai agen flavor dan bahan antibakteri dalam pangan (Gunawan, Supit, \& Manado, 2014). Daun cengkeh juga sering dimanfaatkan sebagai sumber minyak cengkih; hal ini disebabkan minyak cengkih mengandung senyawa etanol yang memiliki kandungan flavonoid, tanin, fenolat, dan minyak atsiri yang memiliki sifat sebagai antiseptik, analgesik, antiinflamasi, antijamur, antibakteri (Leman, 2017). Minyak atsiri cengkeh juga telah diujikan terhadap jamur Candida Albicans. Penelitian yang dilakukan oleh Pratiwietal. Pada tahun 2015 menunjukkan adanya daya hambat minyak atsiri cengkeh terhadap Candida albicans. Penelitian tersebut menggunakan minyak atsiri dari ekstrak daun cengkeh yang juga memiliki komponen utama eugenol (Musta \& Nurliana, 2019). Kandungan senyawa fenolik maka minyak daun cengkeh berpotensi untuk dikembangkan sebagai antijamur. Minyak daun cengkeh dapat menghambat pertumbuhan jamur $C$. albicans disebabkan adanya senyawa fenol dan asam-asam organik yang terkandung di dalam fraksi hasil pirolisis (Islaeli et al., 2019).

Minyak atsiri daun cengkeh (Syzygiumar omaticum) dilaporkan dapat menekan pertumbuhan Phytophthoracapsici secara in vitro, kemungkinan besar tanaman cengkeh memiliki aktivitas antijamur karena adanya senyawa eugenol yang tinggi pada minyak atsiri tersebut (Aulifa, Aryantha, \& Sukrasno, 2014). American Type Culture Collection menunjukkan aktivitas penghambatan terhadap semua mikroba yang diuji. Minyak cengkeh secara signifikan mampu menekan pertumbuhan mikroba. Hal inilah yang menjadi alasan digunakannya minyak atsiri daun cengkeh sebagai bahan anti jamur (Mbatu, Kenanda, Suharta, \& Rita, 2018). Hasil uji aktivitas antijamur minyak atsiri daun cengkeh terhadap jamur Candida albicans memiliki daya hambat sebesar $15 \mathrm{~mm}$. Hasil uji aktivitas anti jamur menunjukkan bahwa minyak atsiri daun cengkeh memiliki daya hambat kuat terhadap pertumbuhan jamur Candida albicans. Uji daya hambat minyak atsiri daun cengkeh terhadap jamur Candida albicans pada konsentrasi 0,5\% sampai 10\% menunjukkan adanya perbedaan nyata, dan Minimum Inhibitory Concentration (MIC) minyak atsiri daun cengkeh terhadap jamur Candida albicans sebesar 0,5\% dengan daya hambat sebesar 5,67 mm (Mbatu et al., 2018).

\section{Metode penelitian}

Desain penelitian eksperiment di laboratorium dengan menggunakan desain The Posttest Only Control Group Design, dalam banyak hal, diasumsikan bahwa dalam suatu populasi tertentu, tiap unit populasi adalah homogen, itu artinya semua karakteristik antar unit populasi adalah sama. Maka pengukuran awal tidak dilakukan karena dianggap sama untuk semua kelompok, karena berasal dari populasi yang sama. Berdasarkan asumsi tersebut maka dikembangkan rancangan eksperimen tanpa ada pengukuran awal (pretest) tetapi hanya ada postest saja. Populasi dan sampel dalam peneitian ini adalah : Semua sputum dari pasien yang melakukan pemeriksaan BTA dengan hasil BTA Positif dan BTA negatif. Sampel dalam peneitian ini adalah : Sebagian sputum dari pasien yang melakukan pemeriksaan BTA dengan hasil BTA Positif dan BTA negatif. Besar unit penelitian yang berupa sampel sputum yang dibutuhkan menggunakan jumlah sampel minimal yaitu 30 sampel (15 sampel BTA positif dan 15 sampel BTA negative). Masing - masing sampel sputum dilakukan kultur pada media TURLM formla 3 kombinasi 1, kombinasi 2, kombinasi 3, media Loweinstein Jensen dan media TURLM tanpa bubuk cengkeh. Pengambilan sampel sputum dilakukan dengan teknik non random accidental sampling yaitu dengan pengambilan sampel secara kebetulan ada di wilayah penelitian yang melakukan pemeriksaan BTA dengan hasil sampel sputum dengan BTA positif baru bukan BTA positif dengan MDR dan sampel Sputum BTA dengan hasil BTA negative. Variabel Bebas : formulasi kombinasi bubuk bunga Cengkeh 
TURLM formula 3. Variabel terikat : Penghambatan jamur kontaminan, Koloni pertumbuhan M. tuberculosis dan Angka Kesuburan M. tuberculosis.

Pengumpulan data meliputi : Cara Pembuatan tepung ikan teri laut, tepung ubi jalar ungu, tepung rumput laut, media TURLM dan media standart Loweinstein - Jensen. Kemudian semua tabung kultur diinkubasi pada $37^{\circ} \mathrm{C}$ dan diamati setiap hari dari minggu pertama masa inkubasi sampai akhir minggu ke-8. Observasi dilakukan dengan melihat pertumbuhan $M$. tuberculosis berdasarkan kecepatan pertumbuhan koloni, jumlah koloni dan angka kesuburan pertumbuhan koloni. Untuk memastikan koloni yang tumbuh adalah $M$. tuberculosis maka dilakukan pemeriksaan mikroskopis dengan pewarnaan BTA. Data dari hasil pengamatan pertumbuhan koloni pada masing - masing media formula kombinasi Bubuk bunga CengkehTURLM Formula 3 (tiga) dan media pembandingan Loweinstein - Jensen dilakukan analisis secara deskriptif.

\section{Hasil penelitian}

a. Tekstur warna media formulasi bubuk bunga Cengkeh (Syzygium aromaticum ) dalam media Teri Ubi Rumput Laut Medium (TURLM) Formula 3 Sebagai Zat Penghambat Jamur Kontaminan pada Biakan Mycobacterium tuberculosis.

Media Formula kombinasi Bubuk bunga CengkehTURLM 3 yaitu TURLM Formula 3 Kombinasi 1 dengan komposisi media : Tepung Ikan Teri Laut 50,1 gram, Tepung Ubi Jalar Ungu 45 gram, Tepung Rumput Laut 4,5 gram, Agar - Agar 15 gram, Gliserol 12 ml, Bubuk bunga Cengkeh 5 gram dan Aquadest $1000 \mathrm{ml}$. TURLM Formula 3 Kombinasi 2 dengan komposisi media: Tepung Ikan Teri Laut 50,1 gram, Tepung Ubi Jalar Ungu 45 gram, Tepung Rumput Laut 4,5 gram, Agar - Agar 15 gram, Gliserol 12 ml, Bubuk bunga Cengkeh 10 gram dan Aquadest 1000 ml. TURLM Formula 3 Kombinasi 3 dengan komposisi media : Tepung Ikan Teri Laut 50,1 gram, Tepung Ubi Jalar Ungu 45 gram, Tepung Rumput Laut 4,5 gram, Agar - Agar 15 gram, Gliserol 12 ml, Bubuk bunga Cengkeh 15 gram dan Aquadest 1000 ml. Masing - masing campuran formula di masukkan dalam beker glass di panaskan sampai mendidih, dimasukkan dalam tabung ulir sebanyak $7 \mathrm{ml}$, disteril 121 derajat Celsius selama 15 menit, medium dimiringkan sampai membeku, selanjutnya dilakukan uji stabilitas medium sebelum digunakan. Adapun deskripsi data dan gambaran tekstur dari media TURLM 3 tanpa dan dengan bubuk cengkeh, masing masing formulasi media dapat dilihat pada tabel 1, gambar 1.

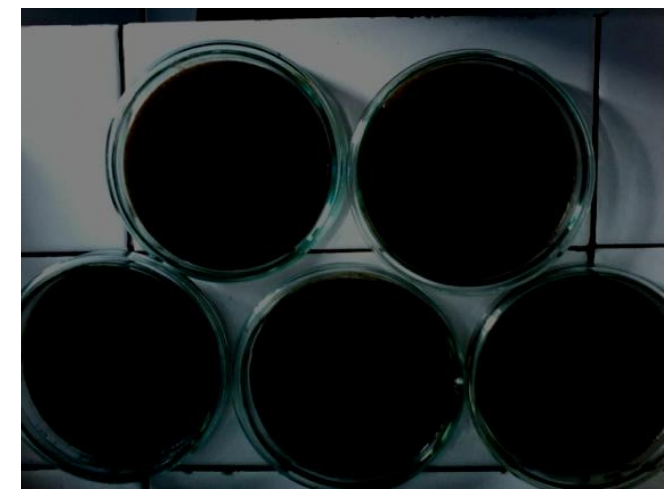

Gambar 1 Tekstur media formulasi bubuk bunga Cengkeh (Syzygium aromaticum) dalam media Teri Ubi Rumput Laut Medium (TURLM) Formula 3 dalam petridisk 

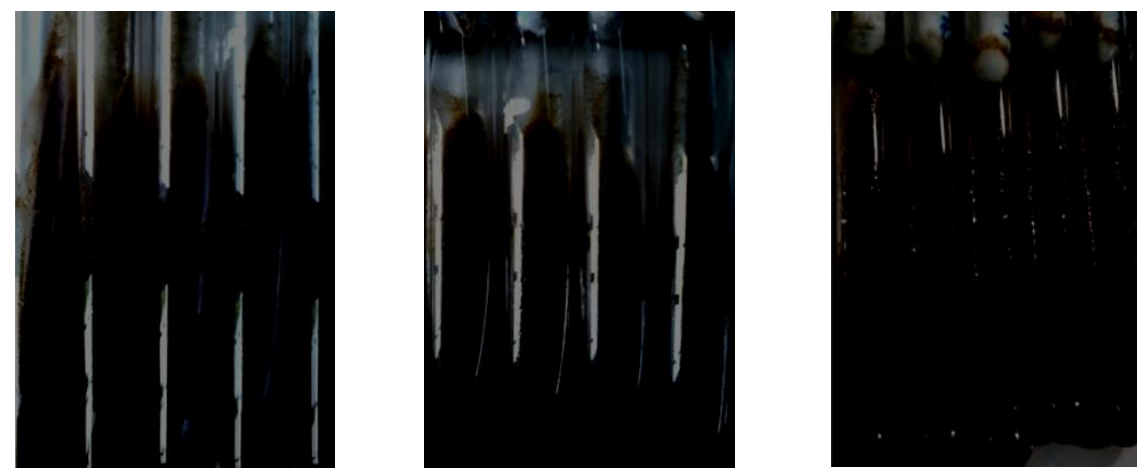

Gambar 2 Tekstur media formulasi bubuk bunga Cengkeh (Syzygium aromaticum) dalam media Teri Ubi Rumput Laut Medium (TURLM) Formula 3 dalam tabung

Tabel 1. Data tekstur media Formula kombinasi Bubuk bunga Cengkeh TURLM 3 Kombinasi 1, 2, 3 dan media TURLM formula 3 tanpa bubuk cengkeh

\begin{tabular}{|c|c|c|c|c|c|}
\hline \multirow[t]{2}{*}{ Formula } & \multicolumn{5}{|c|}{ Tekstur Media } \\
\hline & Warna & Kekerasan & $\mathrm{Bau}$ & Homogenitas & Permukaan \\
\hline F1 & $\begin{array}{l}\text { Coklat lebih } \\
\text { muda }\end{array}$ & solid & $\begin{array}{l}\text { Aroma cengkeh } \\
\text { Keras }\end{array}$ & Baik/homogen & Halus \\
\hline $\mathrm{F} 2$ & Cokat Pekat & solid & $\begin{array}{l}\text { Aroma cengkeh } \\
\text { Keras }\end{array}$ & Baik/homogen & Halus \\
\hline F3 & Coklat Pekat & solid & $\begin{array}{l}\text { Aroma cengkeh } \\
\text { Keras }\end{array}$ & Baik/homogen & Halus \\
\hline KM & $\begin{array}{l}\text { Coklat lebih } \\
\text { muda }\end{array}$ & solid & Aroma ikan laut & Baik/homogen & Halus \\
\hline
\end{tabular}

Keterangan : F1 - F3: Formula 1 - Formula 3, KM: Kontrol media TURLM tanpa bubuk cengkeh

Tabel 1 menunjukkan bahwa selain warna dari gambaran tekstur media antara ketiga formula tersebut tidak menunjukkan perbedaan yang signifikan baik dalam tekstur kekerasan, hogenitas, bau dan permukaan. Untuk warna media antara formula 2 dan formula 3 menunjukkan warna yang tidak berbeda yaitu coklat pekat, sedangkan untuk formula 1 memberikan warna coklat sedikit muda. Sedangkan tekstur media TURLM formula 3 tanpa bubu cengkeh adalah warna coklat lebih muda, kekerasan media solid, permukaan halus dan homogenitas bercampur rata atau baik.

b. Data hasil pertumbuhan M. tuberculosis dan jamur kontaminan berdasarkan positifitas pertumbuhan koloni pada media formulasi bubuk bunga Cengkeh (Syzygium aromaticum ) dalam media Teri Ubi Rumput Laut Medium (TURLM) Formula 3, media standart Loweinstein - Jensen dan TURLM formula 3 tanpa bubuk cengkeh.

Hasil pertumbuhan M. tuberculosis dan jamur kontaminan berdasarkan kecepatan pertumbuhan koloni pada formulasi bubuk bunga Cengkeh (Syzygium aromaticum ) dalam media Teri Ubi Rumput Laut Medium (TURLM) Formula 3, pembanding media standart Loweinstein - Jensen dan media TURLM formula 3 tanpa bubuk cengkeh diobservasi setiap hari sejak mulai dilakukan inokulasi sampai dengan batas pengamatan 8 minggu. Observasi perhitungan pertumbuhan kokoni $M$. tuberculosis dihentikan jika tidak didapatkan pertumbuhan koloni pada media formulasi bubuk bunga Cengkeh (Syzygium aromaticum) 
dalam media Teri Ubi Rumput Laut Medium (TURLM) Formula 3, media standart Loweinstein - Jensen dan media TURLM formula 3 tanpa bubuk cengkehsetelah minggu ke -8. Adapun data hasil perhitungan positivitas pertumbuhan $M$. tuberculosis dan jamur kontaminan pada formulasi bubuk bunga Cengkeh (Syzygium aromaticum) dalam media Teri Ubi Rumput Laut Medium (TURLM) Formula 3, media standart Loweinstein - Jensen dan media TURLM formula 3 tanpa bubuk cengkeh dapat dilihat pada tabel 2 dan 3.

Tabel 2. Positifitas pertumbuhan koloni M. tuberculosis dan jamur kontaminan pada formulasi bubuk bunga Cengkeh (Syzygium aromaticum) dalam media Teri Ubi Rumput Laut Medium (TURLM) Formula 3 dengan pembanding media standart Loweinstein - Jensen dan media TURLM formula 3 tanpa bubuk cengkeh.

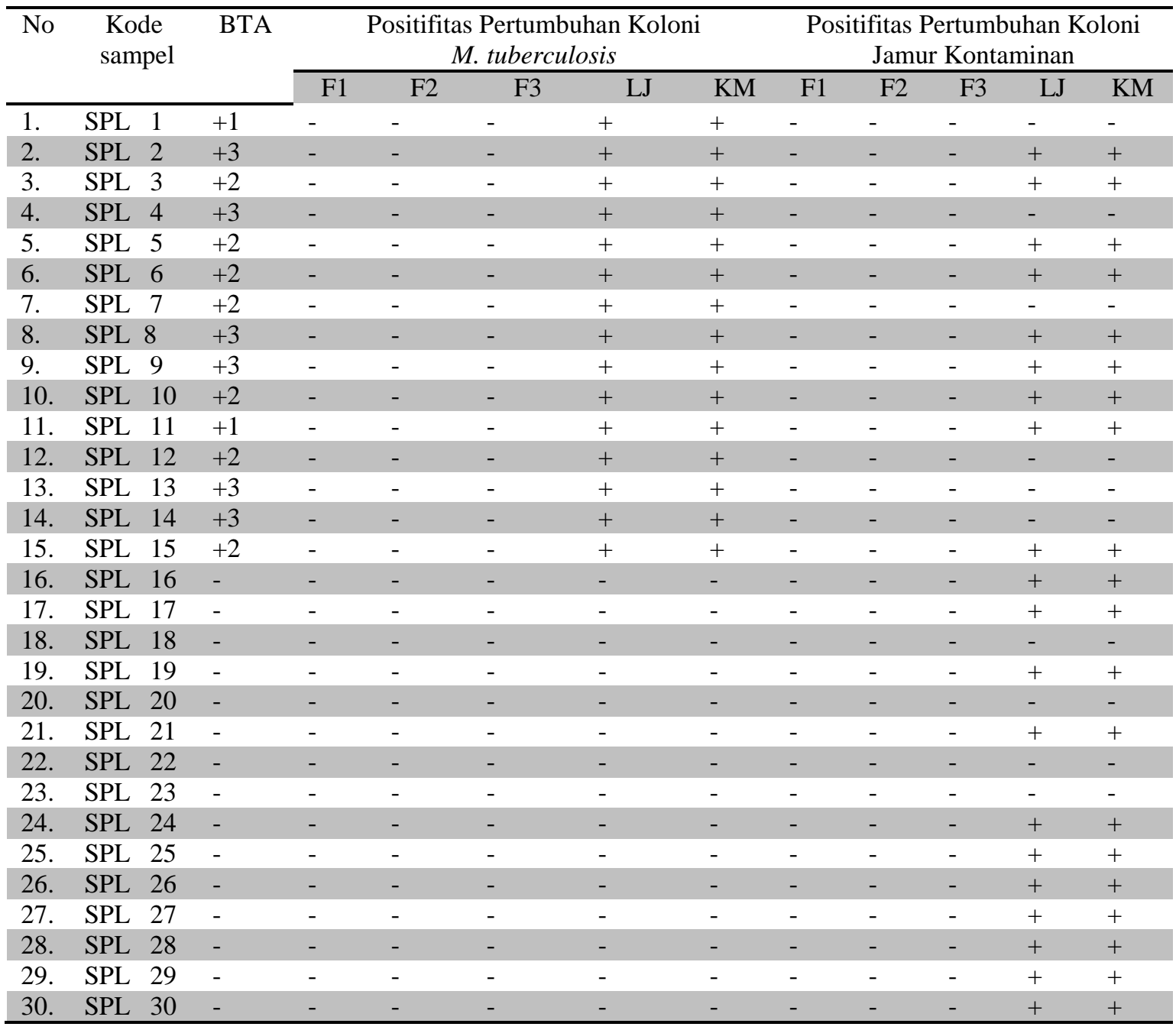

Keterangan :

SPL $1-15 \quad$ : Sampel sputum $1-5$ dengan hasil BTA (+)

SPL $16-30 \quad$ : Sampel sputum $1-5$ dengan hasil BTA (-)

BTA : Bakteri Tahan Asam

F1 : Formula 1

F2 : Formula 2

F3 : Formula 3

LJ : Media Loweinstein-Jensen

KM : Kontrol media TURLM tanpa bubuk cengkeh

Tabel 2 menunjukkan bahwa hasil pertumbuhan M. tuberculosis dari kode sampel sputum SPL 1 - 15 yang menunjukkan hasil smear direct BTA (+) pada media formulasi bubuk bunga Cengkeh (Syzygium aromaticum ) dalam media Teri Ubi Rumput Laut Medium (TURLM) formula 3 baik pada formulasi 1,2 dan 3 sampai dengan minggu ke -8 pengamatan menunjukkan hasil pertumbuhan $M$. tuberculosis negatif, sedangkan pada media pembanding baik pada media standart Loweinstein - Jensen 
dan media TURLM formula 3 tanpa bubuk semuanya menunjukkan hasil pertumbuhan positif sejak hari ke 5 pada minggu-1 pengamatan. Pada sampel dengan kode sampel SPL 16 - 30 yang menunjukkan hasil smear direct BTA (-) menunjukkan semua hasil pertumbuhan $M$. tuberculosis negative baik dalam media formulasi bubuk bunga Cengkeh (Syzygium aromaticum) dalam media Teri Ubi Rumput Laut Medium (TURLM) formula 3 dengan pembanding media standart Loweinstein - Jensen dan media TURLM formula 3 tanpa bubuk cengkeh.

Pertumbuhan jamur kontaminan pada kode sampel SPL 16 - 30 yang menunjukkan hasil smear direct BTA (-) pada media formulasi bubuk bunga Cengkeh (Syzygium aromaticum) dalam media Teri Ubi Rumput Laut Medium (TURLM) formula 3 baik pada formulasi 1,2 dan 3 juga menunjukkan semua hasil pertumbuhan jamur kontaminan negative, sedangkan pada media pembanding yaitu media standar Loweinstein - Jensen menunjukkan 4 dari 15 (26,7 \%) dari sampel hasilnya negatif (tidak tumbuh jamur kontaminan) dan 11 dari 15 (73,3\%) dari sampel hasilnya positif (tumbuh jamur kontaminan). Hal ini menunjukkan bahwa media formulasi bubuk bunga Cengkeh (Syzygium aromaticum) dalam media Teri Ubi Rumput Laut Medium (TURLM) formula 3 baik pada formulasi 1,2 dan 3 menunjukkan hasil pertumbuhan negative tidak didapatkan pertumbuhan jamur kontaminan sama sekali.

c. Data hasil pola waktu kecepatan pertumbuhan $M$. tuberculosis dan jamur kontaminan berdasarkan positifitas pertumbuhan koloni pada media formulasi bubuk bunga Cengkeh (Syzygium aromaticum) dalam media Teri Ubi Rumput Laut Medium (TURLM) Formula 3, media standart Loweinstein - Jensen dan TURLM formula 3 tanpa bubuk cengkeh.

Tabel 3 Pola waktu kecepatan pertumbuhan M. tuberculosis koloni M. tuberculosis dan jamur kontaminan pada formulasi bubuk bunga Cengkeh (Syzygium aromaticum) dalam media Teri Ubi Rumput Laut Medium (TURLM) Formula 3 dengan pembanding media standart Loweinstein - Jensen dan media TURLM formula 3 tanpa bubuk cengkeh.

\begin{tabular}{|c|c|c|c|c|c|c|c|c|c|c|c|c|}
\hline \multirow[t]{2}{*}{ No } & \multirow[t]{2}{*}{$\begin{array}{l}\text { Kode } \\
\text { sampel }\end{array}$} & \multirow[t]{2}{*}{ BTA } & \multicolumn{5}{|c|}{$\begin{array}{l}\text { Waktu kecepatan Pertumbuhan Koloni } \\
\text { M. tuberculosis/Hari }\end{array}$} & \multicolumn{5}{|c|}{$\begin{array}{l}\text { Waktu kecepatan Pertumbuhan } \\
\text { Koloni Jamur Kontaminan/hari }\end{array}$} \\
\hline & & & F1 & $\mathrm{F} 2$ & F3 & KM & $\mathrm{LJ}$ & F1 & $\mathrm{F} 2$ & F3 & KM & $\overline{\mathrm{LJ}}$ \\
\hline 1. & SPL 1 & +1 & - & - & - & 5 hari & 5 hari & - & - & - & - & - \\
\hline 2. & SPL 2 & +3 & - & - & - & 5 hari & 5 hari & - & - & - & 2 hari & 3 hari \\
\hline 3. & SPL 3 & +2 & - & - & - & 5 hari & 5 hari & - & - & - & 3 hari & 3 hari \\
\hline 4. & SPL 4 & +3 & - & - & - & 5 hari & 5 hari & - & - & - & - & - \\
\hline 5. & SPL 5 & +2 & - & - & - & 5 hari & 5 hari & - & - & - & 3 hari & 2 hri \\
\hline 6. & SPL 6 & +2 & - & - & - & 5 hari & 5 hari & - & - & - & 1 hari & 2 hari \\
\hline 7. & SPL 7 & +2 & - & - & - & 5 hari & 5 hari & - & - & - & - & - \\
\hline 8. & SPL 8 & +3 & - & - & - & 5 hari & 5 hari & - & - & - & 2 hari & 2 hari \\
\hline 9. & SPL 9 & +3 & - & - & - & 5 hari & 5 hari & - & - & - & 2 hari & 2 hari \\
\hline 10. & SPL 10 & +2 & - & - & - & 5 hari & 5 hari & - & - & - & 2 hari & 2 hari \\
\hline 11. & SPL 11 & +1 & - & - & - & 5 hari & 5 hari & - & - & - & 2 hari & 2 hari \\
\hline 12. & SPL 12 & +2 & - & - & - & 5 hari & 5 hari & - & - & - & - & - \\
\hline 13. & SPL 13 & +3 & - & - & - & 5 hari & 5 hari & - & - & - & - & - \\
\hline 14. & SPL 14 & +3 & - & - & - & 5 hari & 5 hari & - & - & - & - & - \\
\hline 15. & SPL 15 & +2 & - & - & - & 5 hari & 5 hari & - & - & - & 2 hari & 2 hari \\
\hline 16. & SPL 16 & - & - & - & - & - & - & - & - & - & 2 hari & 2 hari \\
\hline 17. & SPL 17 & - & - & - & - & - & - & - & - & - & 2 hari & 2 hari \\
\hline 18. & SPL 18 & - & - & - & - & - & - & - & - & - & - & - \\
\hline 19. & SPL 19 & - & - & - & - & - & - & - & - & - & 1 hari & 1 hari \\
\hline 20. & SPL 20 & - & - & - & - & - & - & - & - & - & - & - \\
\hline 21. & SPL 21 & - & - & - & - & - & - & - & - & - & 1 hari & 1 hari \\
\hline 22. & SPL 22 & - & - & - & - & - & - & - & - & - & - & - \\
\hline 23. & SPL 23 & - & - & - & - & - & - & - & - & - & - & - \\
\hline 24. & SPL 24 & - & - & - & - & - & - & - & - & - & 3 hari & 3 hari \\
\hline 25. & SPL 25 & - & - & - & - & - & - & - & - & - & 2 hari & 2 hari \\
\hline 26. & SPL 26 & - & - & - & - & - & - & - & - & - & 2 hari & 2 hari \\
\hline 27. & SPL 27 & - & - & - & - & - & - & - & - & - & 3 hari & 3 hari \\
\hline 28. & SPL 28 & - & - & - & - & - & - & - & - & - & 3 hari & 3 hari \\
\hline 29. & SPL 29 & - & - & - & - & - & - & - & - & - & 1 hari & 1 hari \\
\hline
\end{tabular}




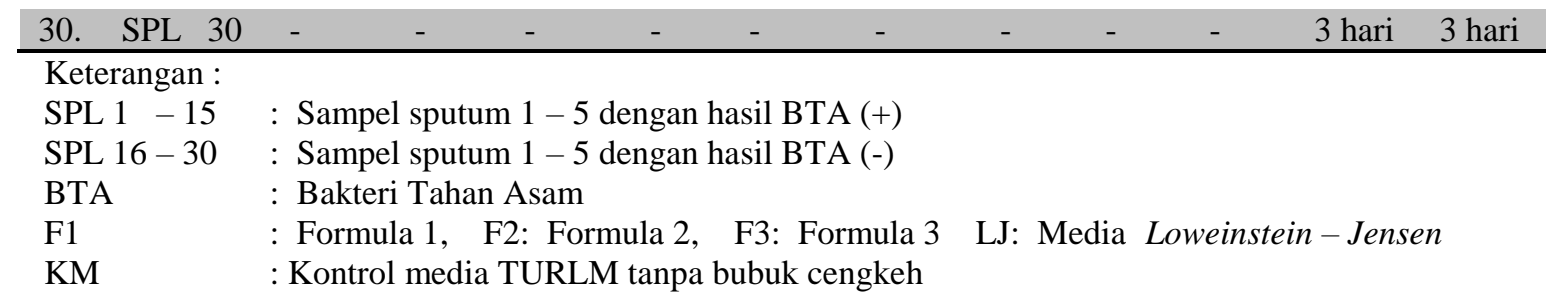

Kecepatan pertumbuhan koloni M. tuberculosis untuk koloni pertama kali tumbuh seperti terlihat pada tabel 3 menunjukkan bahwa dari kode sampel sputum SPL 1 - 15 yang menunjukkan hasil smear direct BTA (+) pada media formulasi bubuk bunga Cengkeh (Syzygium aromaticum ) dalam media Teri Ubi Rumput Laut Medium (TURLM) formula 3 baik pada formulasi 1,2 dan 3 sampai dengan minggu ke 8 pengamatan menunjukkan hasil pertumbuhan $M$. tuberculosis negative sehingga pola waktu kecepatan pertumbuhannya juga negative (0 hari), sedangkan pada media pembanding baik pada media standart Loweinstein - Jensen dan media TURLM formula 3 tanpa bubuk dengan sampel sputum BTA $(+1,+2$ dan +3 ) semuanya menunjukkan hasil pola kecepatan pertumbuhan positif yang sama yaitu munculnya koloni M. tuberculosis sejak hari ke 5 pada minggu-1 pengamatan.

Pada sampel dengan kode sampel SPL 16 - 30 yang menunjukkan hasil smear direct BTA (-) menunjukkan semua hasil pertumbuhan $M$. tuberculosis negative artinya pola waktu kecepatan pertumbuhan $M$. tuberculosis negative (0 hari) baik dalam media formulasi bubuk bunga Cengkeh (Syzygium aromaticum) dalam media Teri Ubi Rumput Laut Medium (TURLM) formula 3 formulasi 1,2 dan 3, media standart Loweinstein - Jensen dan media TURLM formula 3 tanpa bubuk cengkeh. Tabel 3 juga menunjukkan hasil bahwa pola waktu kecepatan pertumbuhan jamur kontaminan dari kode sampel sputum SPL 1 - 30 baik yang menunjukkan hasil smear direct BTA (+) dan BTA (-) pada media formulasi bubuk bunga Cengkeh (Syzygium aromaticum) dalam media Teri Ubi Rumput Laut Medium (TURLM) formula 3 baik pada formulasi 1,2 dan 3 negatif (waktu kecepatan pertumbuhan 0 menit), sedangkan pada media pembanding yaitu media standar Loweinstein - Jensen dan media Teri Ubi Rumput Laut Medium (TURLM) formula 3 tanpa bubuk cengkeh sudah terlihat pertumbuhan sejak hari pertama, dengan interval kecepatan waktu pertumbuhan 1 hari -3 hari.

d. Data Angka kesuburan pertumbuhan M. tuberculosis dan jamur kontaminan berdasarkan positifitas pertumbuhan koloni pada media formulasi bubuk bunga Cengkeh (Syzygium aromaticum) dalam media Teri Ubi Rumput Laut Medium (TURLM) Formula 3, media standart Loweinstein - Jensen dan TURLM formula 3 tanpa bubuk cengkeh.

Tabel 4 Pola Angka kesuburan pertumbuhan M. tuberculosis koloni M. tuberculosis dan jamur kontaminan pada formulasi bubuk bunga Cengkeh (Syzygium aromaticum) dalam media Teri Ubi Rumput Laut Medium (TURLM) Formula 3 dengan pembanding media standart Loweinstein - Jensen dan media TURLM formula 3 tanpa bubuk cengkeh.

\begin{tabular}{|c|c|c|c|c|c|c|c|c|c|c|c|c|}
\hline \multirow[t]{2}{*}{ No } & \multirow[t]{2}{*}{$\begin{array}{l}\text { Kode } \\
\text { sampel }\end{array}$} & \multirow[t]{2}{*}{ BTA } & \multicolumn{5}{|c|}{$\begin{array}{l}\text { Angka kesuburan Pertumbuhan Koloni } \\
\text { M. tuberculosis }\end{array}$} & \multicolumn{5}{|c|}{$\begin{array}{l}\text { Angka kesuburan Pertumbuhan } \\
\text { Koloni Jamur Kontaminan }\end{array}$} \\
\hline & & & F1 & F2 & F3 & $\mathrm{LJ}$ & KM & F1 & F2 & F3 & $\mathrm{LJ}$ & KM \\
\hline 2. & SPL 2 & +3 & - & - & - & 4 & 4 & - & - & - & 4 & 4 \\
\hline 3. & SPL 3 & +2 & - & - & - & 4 & 4 & - & - & - & 4 & 4 \\
\hline 6. & SPL 6 & +2 & - & - & - & 4 & 4 & - & - & - & 4 & 4 \\
\hline 7. & SPL 7 & +2 & - & - & - & 4 & 4 & - & - & - & - & - \\
\hline 8. & SPL 8 & +3 & - & - & - & 4 & 4 & - & - & - & 4 & 4 \\
\hline 9. & SPL 9 & +3 & - & - & - & 4 & 4 & - & - & - & 4 & 4 \\
\hline 13. & SPL 13 & +3 & - & - & - & 4 & 4 & - & - & - & - & - \\
\hline 14. & SPL 14 & +3 & - & - & - & 4 & 4 & - & - & - & - & - \\
\hline 15. & SPL 15 & +2 & - & - & - & 4 & 4 & - & - & - & 4 & 4 \\
\hline 16. & SPL 16 & - & - & - & - & - & - & - & - & - & 4 & 4 \\
\hline
\end{tabular}




\begin{tabular}{|c|c|c|c|c|c|c|c|c|c|c|c|c|c|}
\hline 17. & SPL & 17 & - & - & - & - & - & - & - & - & - & 4 & 4 \\
\hline 18. & SPL & 18 & - & - & - & - & - & - & - & - & - & - & - \\
\hline 20. & SPL & 20 & - & - & - & - & - & - & - & - & - & - & - \\
\hline 21. & SPL & 21 & - & - & - & - & - & - & - & - & - & 4 & 4 \\
\hline 24. & SPL & 24 & - & - & - & - & - & - & - & - & - & 4 & 4 \\
\hline 25. & SPL & 25 & - & - & - & - & - & - & - & - & - & 4 & 4 \\
\hline 26. & SPL & 26 & - & - & - & - & - & - & - & - & - & 4 & 4 \\
\hline 27. & SPL & 27 & - & - & - & - & - & - & - & - & - & 4 & 4 \\
\hline
\end{tabular}

Keterangan :

$\begin{array}{ll}\text { SPL } 1-15 & : \text { Sampel sputum } 1-5 \text { dengan hasil BTA }(+) \\ \text { SPL } 16-30 & : \text { Sampel sputum } 1-5 \text { dengan hasil BTA }(-) \\ \text { BTA } & : \text { Bakteri Tahan Asam } \\ \text { F1 } & : \text { Formula } 1 \\ \text { F2 } & \text { : Formula 2 } \\ \text { F3 } & \text { : Formula 3 } \\ \text { LJ } & : \text { Media Loweinstein - Jensen } \\ \text { KM } & \text { : Kontrol media TURLM tanpa bubuk cengkeh }\end{array}$

Angka kesuburan pertumbuhan koloni M. tuberculosis untuk koloni pertama kali tumbuh seperti terlihat pada tabel 4 menunjukkan bahwa dari kode sampel sputum SPL $1-15$ yang menunjukkan hasil smear direct BTA $(+)$ pada media formulasi bubuk bunga Cengkeh (Syzygium aromaticum ) dalam media Teri Ubi Rumput Laut Medium (TURLM) formula 3 baik pada formulasi 1,2 dan 3 sampai dengan minggu ke -8 pengamatan menunjukkan hasil pertumbuhan $M$. tuberculosis negative sehingga angka kesuburan kecepatan pertumbuhannya adalah 1 (satu), sedangkan pada media pembanding baik pada media standart Loweinstein - Jensen dan media TURLM formula 3 tanpa bubuk dengan sampel sputum BTA $(+1,+2$ dan +3) semuanya menunjukkan hasil pola kecepatan pertumbuhan positif yang sama yaitu 4 (empat).

Pada sampel dengan kode sampel SPL 16 - 30 yang menunjukkan hasil smear direct BTA (-) menunjukkan semua hasil pertumbuhan $M$. tuberculosis negative artinya angka kesuburan pertumbuhan M. tuberculosis 1 (Satu) baik dalam media formulasi bubuk bunga Cengkeh (Syzygium aromaticum) dalam media Teri Ubi Rumput Laut Medium (TURLM) formula 3 formulasi 1,2 dan 3, media standart Loweinstein - Jensen dan media TURLM formula 3 tanpa bubuk cengkeh. Tabel 4 juga menunjukkan hasil bahwa angka kesuburan pertumbuhan jamur kontaminan dari kode sampel sputum SPL 1 - 30 baik yang menunjukkan hasil smear direct BTA (+) dan BTA (-) pada media formulasi bubuk bunga Cengkeh (Syzygium aromaticum) dalam media Teri Ubi Rumput Laut Medium (TURLM) formula 3 baik pada formulasi 1,2 dan 3 adalah 1 (satu), sedangkan pada media pembanding yaitu media standar Loweinstein - Jensen dan media Teri Ubi Rumput Laut Medium (TURLM) formula 3 tanpa bubuk cengkeh sudah terlihat pertumbuhan sejak hari pertama, dengan interval kecepatan waktu pertumbuhan 1 hari -3 hari dengan angka kesuburan 4 (empat).

\section{Pembahasan}

Media pertumbuhan yang umum digunakan dan merupakan gold standart untuk menumbuhkan Mycobacterium tuberculosis adalah Lowenstein-Jensen dan Ogawa yang mengandung malasit green untuk menghambat bakteri lain kemudian memodifikasi dengan citrat dan phosphat. Pemeriksaan dengan metode kultur memiliki beberapa kelemahan yaitu masa inkubasi yang terlalu panjang untuk menghitung pertumbuhan M. tuberculosis yang mencapai 8 minggu untuk bisa menyatakan hasil negatif. Komposisi media LJ yang relatif menggunakan bahan - bahan seperti Potato flour 30.0 gram, Asparagine 3,6 gram, Monopotassium phosphate 2,4 gram, Magnesium citrate 0,6 gram, Malacit green 0,4 gram, Magnesium sulfat 0,24 gram, Whole Eggs $1000,0 \mathrm{ml}$, Gliserol 12,0 $\mathrm{ml}$ dan Demineralized water $600 \mathrm{ml}$, membuat media ini harganya relatif mahal dan memerlukan pembuatan yang khusus yang memerlukan ketelitian (Murray,P.R, dkk,2007). 
Hasil penelitian Rohmi dan Diarti (2017) membuat formula modifikasi media pertumbuhan $M$. tuberculosis yang terbuat dari tepung ikan teri laut, tepung ubi jalar ungu dan tepung rumput laut dengan penambahan gliserol yag diberi nama media TURLM (Teri Ubi Rumput Laut Medium). Dari ketiga formula media TURLM (Teri Ubi Rumput Laut Medium) yang dibuat yang paling baik menunjukkan pertumbuhan koloni dan angka kesuburan pertumbuhan M. tuberculosis yaitu formula 3 (tiga). Hasil penelitian Rohmi dan Diarti (2018) juga menunjukkan bahwa pola sensitivitas dan spesifisitas media Teri Ubi Rumput Laut Medium (TURLM) formula 3 terhadap pertumbuhan $M$. tuberculosis dibandingkan dengan media baku standart Loweinstein - Jensen berdasarkan positifitas pertumbuhan adalah sensitivitas $100 \%$ dan spesifisitas $100 \%$.

Hasil penelitian ini membuktikan media Teri Ubi Rumput Laut Medium (TURLM) formula 3 dapat digunakan untuk alternatife media diagnostik klinik pertumbuhan M. tuberculosis karena memiliki Sensitivitas dan spesifisitas, kecepatan pertumbuhan, jumlah koloni dan angka kesuburan terhadap pertumbuhan $M$. tuberculosis yang baik, namun kelemahan dari formulasi media TURLM formula 3 ini masih terdapat kontaminasi jamur baik pada media kontrol maupun pengujian, sehingga memerlukan data untuk menguji kestabilan dan ketahan media dalam penyimpanan terutama terhadap kontaminasi jamur. Komposisi Formulasi media yang digunakan dalam penelitian ini adalah TURLM Formula 3 dengan penambahan bubuk cengkeh.

Formulasi media menggunakan tiga kombinasi yaitu kombinasi 1 dengan komposisi tepung ikan teri laut 50,1 gram, tepung ubi jalar ungu 45 gram, tepung rumput laut 4,5 gram, agar - agar 15 gram, gliserol 12 $\mathrm{ml}$, bubuk bunga Cengkeh 5 gram dan Aquadest $1000 \mathrm{ml}$. Kombinasi 2 dengan komposisi tepung ikan teri laut 50,1 gram, tepung ubi jalar ungu 45 gram, tepung rumput laut 4,5 gram, agar - agar 15 gram, gliserol 12 $\mathrm{ml}$, bubuk bunga Cengkeh 10 gram dan aquadest $1000 \mathrm{ml}$. Kombinasi 3 dengan komposisi tepung ikan teri laut 50,1 gram, tepung ubi jalar ungu 45 gram, tepung rumput laut 4,5 gram, agar - agar 15 gram, gliserol $12 \mathrm{ml}$, bubuk bunga Cengkeh 15 gram dan aquadest $1000 \mathrm{ml}$. Sampel sputum yang digunakan adalah 15 sputum BTA (+) dan 15 sputum BTA (-).

Hasil penelitian menunjukkan bahwa selain warna dari gambaran tekstur media antara ketiga formula tersebut tidak menunjukkan perbedaan yang signifikan baik dalam tekstur kekerasan, hogenitas, bau dan permukaan. Untuk warna media antara formula 2 dan formula 3 menunjukkan warna yang tidak berbeda yaitu coklat pekat, sedangkan untuk formula 1 memberikan warna coklat sedikit muda. Sedangkan tekstur media TURLM formula 3 tanpa bubuk cengkeh adalah warna coklat lebih muda, kekerasan media solid, permukaan halus dan homogenitas bercampur rata atau baik. Hasil pertumbuhan M. tuberculosis dan jamur kontaminan berdasarkan kecepatan pertumbuhan koloni pada formulasi bubuk bunga Cengkeh (Syzygium aromaticum ) dalam media Teri Ubi Rumput Laut Medium (TURLM) Formula 3, pembanding media standart Loweinstein Jensen dan media TURLM formula 3 tanpa bubuk cengkeh diobservasi setiap hari sejak mulai dilakukan inokulasi sampai dengan batas pengamatan 8 minggu.

Hasil penelitian menunjukkan bahwa baik pada media TURLM formula 3 tanpa bubuk cengkeh dan media standart LJ terdapat pertumbuhan M. tuberculosis dan jamur kontaminan. Ciri pertumbuhan koloni $M$. tuberculosis pada media TURLM formula 3 tanpa bubuk cengkeh adalah bulat, sedikit kasar, kering, rapuh, tengah bertumpuk dengan tepi berjejas tipis; kadang-kadang tipis dan menyebar, berwarna coklat keruh. Pertumbuhan koloni pada media kontrol LJ juga terlihat pertumbuhan mulai pada hari ke-5, dengan ciri morfologi koloni $M$. tuberculosis adalah sebagai berikut: kasar, kering, rapuh, tengah bertumpuk dengan tepi berjejas tipis; kadang-kadang tipis dan menyebar, berwarna kuning muda (cream). Hasil penelitian juga menunjukkan pada media menunjukkan TURLM formula 3 tanpa bubuk cengkeh adanya koloni jamur kontaminan Aspergillus flavus, Aspergillus niger dan bakteri kontaminan Staphylococcus albus.

Pada media kontrol LJ terlihat pertumbuhan mulai pada hari ke-5, dengan ciri morfologi koloni $M$. tuberculosis adalah sebagai berikut: kasar, kering, rapuh, tengah bertumpuk dengan tepi berjejas tipis; kadangkadang tipis dan menyebar, berwarna kuning muda (cream). Gambar (b) Pertumbuhan koloni M. tuberculosis atipikal dan jamur kontaminan Aspergillus flavus. Hasil penelitian menunjukkan bahwa pertumbuhan $M$. tuberculosis dari kode sampel sputum SPL 1 - 15 yang menunjukkan hasil smear direct BTA (+) pada media formulasi bubuk bunga Cengkeh (Syzygium aromaticum) dalam media Teri Ubi Rumput Laut Medium (TURLM) formula 3 baik pada formulasi 1,2 dan 3 sampai dengan minggu ke -8 pengamatan menunjukkan hasil pertumbuhan $M$. tuberculosis negatif, sedangkan pada media pembanding baik pada media standart Loweinstein - Jensen dan media TURLM formula 3 tanpa bubuk semuanya menunjukkan hasil pertumbuhan positif sejak hari ke 5 pada minggu-1 pengamatan.

Hal ini menunjukkan bahwa media formulasi bubuk bunga Cengkeh (Syzygium aromaticum) dalam media Teri Ubi Rumput Laut Medium (TURLM) formula 3 baik pada formulasi 1,2 dan 3 menunjukkan hasil pertumbuhan negative tidak didapatkan pertumbuhan jamur kontaminan sama sekali. Hasil penelitian menunjukkan bahwa kecepatan pertumbuhan koloni $M$. tuberculosis untuk koloni pertama kali tumbuh seperti terlihat pada tabel 4.3 menunjukkan bahwa dari kode sampel sputum SPL 1 - 15 yang menunjukkan hasil smear direct BTA (+) pada media formulasi bubuk bunga Cengkeh (Syzygium aromaticum) dalam media Teri Ubi Rumput Laut Medium (TURLM) formula 3 baik pada formulasi 1,2 dan 3 sampai dengan minggu ke -8 
pengamatan menunjukkan hasil pertumbuhan $M$. tuberculosis negative sehingga pola waktu kecepatan pertumbuhannya juga negative (0 hari), sedangkan pada media pembanding baik pada media standart Loweinstein - Jensen dan media TURLM formula 3 tanpa bubuk dengan sampel sputum BTA $(+1,+2$ dan +3$)$ semuanya menunjukkan hasil pola kecepatan pertumbuhan positif yang sama yaitu munculnya koloni $M$. tuberculosis sejak hari ke 5 pada minggu-1 pengamatan.

Hasil penelitian juga menunjukkan bahwa Angka kesuburan pertumbuhan koloni M. tuberculosis untuk koloni pertama kali tumbuh seperti terlihat pada tabel 4 menunjukkan bahwa dari kode sampel sputum SPL 1 - 15 yang menunjukkan hasil smear direct BTA (+) pada media formulasi bubuk bunga Cengkeh (Syzygium aromaticum ) dalam media Teri Ubi Rumput Laut Medium (TURLM) formula 3 baik pada formulasi 1,2 dan 3 sampai dengan minggu ke -8 pengamatan menunjukkan hasil pertumbuhan $M$. tuberculosis negative sehingga angka kesuburan kecepatan pertumbuhannya adalah 1 (satu), sedangkan pada media pembanding baik pada media standart Loweinstein - Jensen dan media TURLM formula 3 tanpa bubuk dengan sampel sputum BTA $(+1,+2$ dan +3$)$ semuanya menunjukkan hasil pola kecepatan pertumbuhan positif yang sama yaitu 4 (empat).

Penambahan bubuk cengkeh dalam media TURLM formula 3 pada semua formulasi sangat effektif untuk menghambat pertumbuhan jamur kontaminan, namun juga menghambat pertumbuhan M. tuberculosis, walaupun hasil penelitian ini tidak menunjukkan hasil yang diharapkan untuk mencari bahan alam yang ditambahkan pada media TURLM formula 3 dengan tujuan untuk menghambat pertumbuhan jamur kontaminan, tanpa menganggu atau menghambat pertumbuhan, kecepatan waktu pertumbuhan dan angka kesuburan pertumbuhan $M$. tuberculosis, namun hasil penelitian ini mendapatkan penemuan baru di dunia pengobatan TBC karena bubuk cengkeh yang ditambahkan pada media TURLM formula 3 ternyata juga menghambat sama sekali pertumbuhan $M$. tuberculosis, sehingga bisa digunakan, dan secara tradisional digunakan sebagai agen flavor dan bahan antibakteri dalam pangan (Gunawan, Supit, \& Manado, 2014).

Daun cengkih juga sering dimanfaatkan sebagai sumber minyak cengkih; hal ini disebabkan sebagai alternative pengobatan penyakit Tuberculosis yang disebabkan oleh bakteri $M$. tuberculosis. Oleh karena itu perlu penelitian lebih lanjut untuk pembuktian hasil penelitian ini secara molekuler untuk melihat efek penghambatan bubuk cengkeh terhadap M. tuberculosis. Kemampuan penghambatan jamur kontaminan dan M. tuberculosis oleh bubuk cengkeh dari beberapa literatur disebabkan karena tanaman cengkeh (Syzigium aromaticum) merupakan tanaman rempah yang dalam bentuk sediaan minyak cengkeh memiliki aktivitas biologi, antara lain sifat antibakteri, antijamur, pemberantas serangga, dan antioksidanminyak cengkih mengandung senyawa etanol yang memiliki kandungan flavonoid, tanin, fenolat, dan minyak atsiri yang memiliki sifat sebagai antiseptik, analgesik, antiinflamasi, antijamur, antibakteri (Leman, 2017). Semua bagian pohon cengkeh (Syzygium aromaticum ) mengandung minyak atsiri, mulai dari akar, batang, daun sampai bunga. Minyak astiri daun cengkeh terdiri atas eugenol dengan konsentrasi yang lebih tinggi dibandingkan asetil eugenol dan karioeugenol yang juga terkandung di dalam minyak atsiri cengkeh.

Kuncup bunga mengandung 16-23\% minyak atsiri yang terdiri dari eugenol, zat samak tipe gallat, sianidin ramnoglukosida (pigmen utama bunga), kuersetin, kaemferol, mirisetin dan isokuersitrin.Daun cengkeh mengandung asam gallat, metil gallat, turunan triterpen, asam oleanolat (kariofilin), asam betulinat.Kulit batang mengandung asam betulinat, friedelin, epifriedelinol, sitosterim, eugenin (suatu senyawa ester dari epifriedelinol dengan suatu asam lemak rantai panjang), dan $\mathrm{C}_{27} \mathrm{H}_{55} \mathrm{COOH}$. Tanaman cengkeh mengandung beberapa flavonoid,campesterol, karbohidrat, lipid, rhamnetin, sitosterol, stigmasterol dan vitamin (Nassar, 2006). Minyak atsiri pada cengkeh memiliki aktivitas antibakteri terhadap berbagai jenis mikroba seperti Campylobacter jejuni, Salmonella enteritidis, Escherichia coli, dan Stapphylococcus aureus, Porphyromonas gingivalis (Burt and Reinders, 2003; Zhang et al., 2017; Larhsini et al., 2001; Cressy et al., 2003; Friedman et al., 2002; Chaieb et al., 2007).

Selain itu ekstrak cengkeh juga terbukti dapat menghambat proses replikasi virus hepatitis C (HCV) melalui metode in vitro (Hussein et al., 2000). Khasiat lain dari tanaman cengkeh antara lain sebagai, antiemetik (Barnes, dkk., 2002, antikarsinogenik (Zheng, 1992), analgetik, antivirus terutama Herpes simplex (Kurokawa, 1998). Minyak atsiri cengkeh juga telah diujikan terhadap jamur Candida Albicans. Penelitian yang dilakukan oleh Pratiwietal. Pada tahun 2015 menunjukkan adanya daya hambat minyak atsiri cengkeh terhadap Candida albicans. Penelitian tersebut menggunakan minyak atsiri dari ekstrak daun cengkeh yang juga memiliki komponen utama eugenol (Musta \& Nurliana, 2019). Adanya kandungan senyawa fenolik maka minyak daun cengkeh berpotensi untuk dikembangkan sebagai antijamur. Minyak daun cengkeh dapat menghambat pertumbuhan jamur $C$. albicans disebabkan adanya senyawa fenol dan asam-asam organik yang terkandung di dalam fraksi hasil pirolisis (Musta \& Nurliana, 2019). Minyak atsiri daun cengkeh (Syzygiumar omaticum) dilaporkan dapat menekan pertumbuhan Phytophthoracapsici secara in vitro, kemungkinan besar tanaman cengkeh memiliki aktivitas antijamur karena adanya senyawa eugenol yang tinggi pada minyak atsiri tersebut 
(Aulifa, Aryantha, \& Sukrasno, 2014). American Type Culture Collection menunjukkan aktivitas penghambatan terhadap semua mikroba yang diuji. Minyak cengkeh secara signifikan mampu menekan pertumbuhan mikroba. Hal inilah yang menjadi alasan digunakannya minyak atsiri daun cengkeh sebagai bahan antijamur (Mbatu, Kenanda, Suharta, \& Rita, 2018).

Hasil uji aktivitas antijamur minyak atsiri daun cengkeh terhadap jamur Candida albicans memiliki daya hambat sebesar $15 \mathrm{~mm}$. Hasil uji aktivitas anti jamur menunjukkan bahwa minyak atsiri daun cengkeh memiliki daya hambat kuat terhadap pertumbuhan jamur Candida albicans. Uji daya hambat minyak atsiri daun cengkeh terhadap jamur Candida albicans pada konsentrasi 0,5\% sampai $10 \%$ menunjukkan adanya perbedaan nyata, dan Minimum Inhibitory Concentration (MIC) minyak atsiri daun cengkeh terhadap jamur Candida albicans sebesar 0,5\% dengan daya hambat sebesar 5,67 mm (Mbatu et al., 2018). Zat bioaktif lainnya pada bubuk cengkeh yang memiliki efek antijamur, antibiotika dan anti virus adalah senyawa eugenol, eugenol mengandung beberapa gugus fungsi yaitu alil $\left(-\mathrm{CH}_{2}-\mathrm{CH}=\mathrm{CH}_{2}\right)$, fenol $(-\mathrm{OH})$ dan metoksi $\left(-\mathrm{OCH}_{3}\right)$ yang membuat eugenol memiliki kemampuan menghambat polimerasi DNA bakteri dan virus. Senyawa eugenol memiliki sifat lipolitik yang dapat mengakibatkan terjadinya adhesi dengan membrane sel bakteri, jamur dan virus sehingga tekanan osmotik meningkat, menyebabkan kerusakan pada membrane sel dan menghambat respirasi bakteri, jamur dan virus. Terhambatnya proses respirasi akan menimbulkan terganggunya transport ion pada sel sehingga bakteri akan mengalami kematian. Ikatan fenol (-OH) dalam senyawa eugenol jika menempel pada sel bakteri akan membuat bakteri mengalami lisis kemudian mati, karena protein yang dimiliki bakteri mengalami denaturasi sehingga enzim transpeptidase mengalami perubahan struktur dan fungsi yang mengakibatkan gangguan pembentukkan dinding sel bakteri yang tersusun atas peptidoglikan dengan gugus polisakarida dan polipeptida. Dinding sel yang telah rusak dan tak terbentuk mengakibatkan bakteri mati (Towaha dan Yuniati;2012).

Kandungan Daun Cengkeh (Syzygium aromaticum) Daun cengkeh mengandung komponen fenolik yang tinggi yaitu senyawa eugenol 70-80\% senyawa ini bersifat antioksidan. Eugenol mempunyai sifat sebagai stimulan, anestetik lokal, karminatif, antiseptik dan antispasmodik (Nurdjannah, 2004).Senyawa eugenol merupakan komponen utama yang terkandung dalam minyak atsiri cengkeh.Eugenol mengandung senyawa aktif seperti saponin, flavonoid, tannin, dan minyak atsiri (Rorong, 2008). Daun cengkeh memiliki kandungan minyak atsiri 1-4\%, yang dapat dimanfaatkan sebagai obat. Menurut Talahatu (2015) pemisahan kandungan kimia dari bunga cengkeh, tangkai cengkeh dan daun cengkeh yang menunjukkan bahwa bunga cengkeh dan daun cengkeh mengandung saponin, alkaloid, flavonoid, glikosida, tannin dan minyak atsiri sedangkan tangkai bunga cengkeh mengandung saponin, tannin, alkaloid, glikosida, flavonoid dan minyak atsiri. Pemanfaatan tanaman cengkeh di Sulawesi Utara sebagian besar hanya mencakup bagian bunganya saja sedangkan bagian daun hanya dianggap sebagai limbah, padahal di dalam daun cengkeh terkandung suatu komponen minyak atsiri dan komponen fenolik yang selama ini kurang dimanfaatkan secara maksimal (Rorong, 2008).

Komponen fenolik merupakan antioksidan alami yang bermanfaat bagi manusia, antioksidan merupakan senyawa penting dalam menjaga kesehatan tubuh yang terbukti sebagai pelidung melawan efek bahaya radikal bebas dan diketahui pula mampu menurunkan resiko kanker, obat sakit gigi, penyakit jantung coroner, stroke, artherosclerosis, ospteoporosis, inflamasi, penyakit neurodegeneratif, dan produk aroma terapi (Lumingkewas dkk., 2014). Hasil penelitian ini menunjukkan bahwa media TURLM formula 3 yang ditambahkan bubuk cengkeh pada semua formula mampu membuktikan adanya penghambatan jamur kontaminan, namun juga menghambat pertumbuhan $M$. tuberculosis. Selain kandungan senyawa bioaktif yang sangat kuat pada bubuk cengkeh sehingga mampu menghambat pertumbuhan M. tuberculosis, kemungkinan disebabkan pula karena dosis atau kadar bubuk cengkeh yang ditambahkan pada media TURLM formula 3 terlalu tinggi, sehingga perlu dilakukan penelitian lanjutan untuk mengamati pertumbuhan $M$. tuberculosis dan jamur kontaminan menggunakan kadar terkecil dengan menentukan Minimal Inhibitor Concentration (MIC) sehingga bisa ditentukan konsentrasi terkecil dari bubuk cengkeh yang ditambahkan pada media TURLM formula 3 yang hanya dapat menghambat pertumbuhan jamur tanpa menghambat pertumbuhan $M$. tuberculosis. Selama penelitian ini berlangsung tidak ada masalah, semua berjalan sesuai dengan rencana yang telah dibuat oleh peneliti.

\section{Kesimpulan}

Media TURLM formula 3 tanpa bubuk cengkeh dan Loweinstein - Jenssen menunjukkan pertumbuhan koloni jamur kontaminan Aspergillus flavus, Aspergillus niger dan bakteri kontaminan Staphylococcus albus sedangkan pada media formulasi bubuk bunga Cengkeh (Syzygium aromaticum ) dalam media Teri Ubi Rumput Laut Medium (TURLM) formula 3 baik pada formulasi 1,2 dan 3 sampai dengan minggu ke -8 pengamatan menunjukkan hasil pertumbuhan koloni jamur kontaminan dan $M$. tuberculosis negative. Kecepatan pertumbuhan koloni $M$. tuberculosis dan koloni jamur kontaminan untuk koloni pertama kali tumbuh pada media formulasi bubuk bunga Cengkeh (Syzygium aromaticum) dalam media Teri Ubi Rumput Laut Medium (TURLM) formula 3 baik pada formulasi 1,2 dan 3 sampai dengan minggu ke -8 menunjukkan 
hasil pertumbuhan negative sehingga pola waktu kecepatan pertumbuhannya juga negative ( 0 hari), sedangkan pada media pembanding baik pada media standart Loweinstein - Jensen dan media TURLM formula 3 tanpa bubuk bunga cengkeh dengan sampel sputum BTA $(+1,+2$ dan +3$)$ semuanya menunjukkan hasil pola kecepatan pertumbuhan positif yang sama yaitu munculnya koloni $M$. tuberculosis sejak hari ke 5 pada minggu-1 pengamatan. Angka kesuburan pertumbuhan koloni M. tuberculosis dan koloni jamur kontaminan untuk koloni pertama kali tumbuh pada media formulasi bubuk bunga Cengkeh (Syzygium aromaticum ) dalam media Teri Ubi Rumput Laut Medium (TURLM) formula 3 baik pada formulasi 1,2 dan 3 sampai dengan minggu ke -8 menunjukkan hasil pertumbuhan negative sehingga angka kesuburan kecepatan pertumbuhannya adalah 1 (satu), sedangkan pada media pembanding baik pada media standart Loweinstein - Jensen dan media TURLM formula 3 tanpa bubuk dengan sampel sputum BTA $(+1,+2$ dan +3$)$ semuanya menunjukkan hasil pola kecepatan pertumbuhan positif yang sama yaitu 4 (empat).

\section{Daftar pustaka}

Asa M, 2005. Harapan dan tantangan aplikasi reaksi rantai polimerase (PCR) Multipleks dalam pemberantasan TB Paru di Indonesia (suatu pendekatan biologi molekuler). Suplement vol 26.

Aulifa, D. ., Aryantha, I. N. ., \& Sukrasno. (2014). Aktivitas Anti Jamur Ekstrak Metanol Dari Tumbuhan Rempah-Rempahan, 16(1), 10-15.

Barnes J, Anderson LA dan Phillipson JD. Herbal interaction.The Pharmaceutical Journal. 270: 118-121, 2003.

Burt SA dan Reinders RD. 2003. Antibacterial activity of selected plant essential oils against Escherichia coli O157:H7. Lett Appl Microbiol. 36(3):162-7.

Budiarto dan Anggraeni,2003. Pengantar epidemiologi Edisi 2.Jakarta ; Penerbit Buku kedokteran EGC.

Chaieb K, Hajlaoui H, Zmantar T, Kahla-Nakbi AB, Rouabbhia M, Mahdouani K, Bakhrouf A 2007. The chemical composition and biological activity of clove essential oil, Eugenia caryophyllata (Syzigium aromaticum L. Myrtaceae): a short review. Phytother Res 21: 501-506.

Crofton SJ; Horne N; Miller F, 2002, Tuberkulosis Klinis, Widya Medika, Jakarta

Gunawan, P. N., Supit, A., \& Manado, S. R. (2014). Uji Efek Anti Bakteri Ekstrak Bunga Cengkeh, 2.

Islaeli, B. N., Diarti, M. W., \& Jiwintoro, Y. A. (2019). Pemanfaatan larutan garam natrium klorida (nacl) sebagai pengawet alternatif pada urine untuk pemeriksaan urine metode carik celup. Jurnal Analis Medika Biosains (JAMBS). https://doi.org/10.32807/jambs.v6i1.123

Kurokawa M, Hozumi T, Basnet P, Nakano M, Kadota S, Namba T, Kawana T, Shiraki K. 1998. Purification and characterization of eugeniin as an anti-herpesvirus compound from Geum japonicum and Syzygium aromaticum.J Pharmacol Exp Ther. 284(2):728-35.

Larhsini M, Oumoulid L, Lazrek HB, Wataleb S, Bousaid M, Bekkouche K, Jana M 2 001. Antibacterial activity of some Maroccan medicinal plants. Phytother Res 15: 250-252.

Leman, M. A. (2017). Uji daya hambat ekstrak daun cengkih ( Syzygium aromaticum ( L .) ) terhadap bakteri Enterococcus faecalis, 5 .

Lasinrang Aditia,2014. Rumput Laut (Euchema spinosum). Makalah ilmiah Jurusan Biologi Fakultas Sains dan teknologi Universitas Islam Negeria Alauddin MakassarMbatu, S. T., Kenanda, I. P. B., Suharta, I. G. Y., \& Rita, S. (2018). Aktivitas Minyak Atsiri Daun Cengkeh Sebagai Antijamur Terhadap Candida albicans, 2(1), 61-65.

Musta, R., \& Nurliana, L. (2019). Studi Kinetika Efektifitas Minyak Daun Cengkeh (Syzigium aromaticum) Sebagai Antifungsi Candida albicans, 6(2), 107-114. 
Murray. 2005. Buku Ajar Mikrobiologi. Penerbit Buku Kedokteran EGC, Jakarta.

Nassar, M. I. (2006). Flavonoid triglycosides from the seeds of Syzygium aromaticum.Carbohydr Res 341(1), 160-3.

Nurdjannah, N. (2016). Diversifikasi Penggunaan Cengkeh, (12).

Rohmi dan Diarti MW,2017. Analisis Formula Modifikasi Tepung Ikan Teri, Rumput Laut Dan Ubi Jalar Ungu Sebagai Media Alternatif Pertumbuhan Mycobacterium Tuberculosis". Laporan akhir penelitian pengembangan penelitian dosen Poltekkes Kemenkes Mataram Skema Penelitian Dosen Pemula.

Rohmi dan Diarti MW,2018. Pola Nilai Sensitivitas dan Spesifisitas dan Media Teri Ubi Rumput Laut Medum (TURLM) Formula 3 Terhadap Pertumbuhan Mycobacterium Tuberculosis. Laporan akhir penelitian pengembangan penelitian dosen Poltekkes Kemenkes Mataram Skema Penelitian Dosen Pemula.

Towaha dan Yuniaty.2012. Manfaat eugenol Cengkeh dalam berbagai industry di Indonesia. Jurnal Persepektif. Volume 11 edisi 2 , halaman 79-90.

Wiwit PL,2015. Kandungan Kadar Protein dan Air dalam Ikan Teri (Stolephorus Sp) Asin dengan Oven sebagai alternative Pengganti Panas Matahari.

Zhang Yi, YueWang, Xiaojing Zhu, Ping Cao, Shaomin Wei, Yanhua Lu. 2017. Antibacterial and antibiofilm activities of eugenol from essential oil of Syzygium aromaticum (L.) Merr.\& L. M. Perry (clove) leaf against periodontal pathogen Porphyromonas gingivalis. Elsevier. 113(12): 396402. 